Session 2222

\title{
Distance Education, Undergraduate Programs, and Accreditation ${ }^{1}$
}

\author{
Edwin C. Jones, Jr. \\ Iowa State University
}

\begin{abstract}
Distance Education in engineering, long a fixture at the graduate level, is now becoming feasible at the undergraduate level. The challenges are great, but challenges lead to opportunities, and this opportunity is that of contributing to an important national need.
\end{abstract}

ABET is considering the ramifications of distance education, and has studied the question, especially as accreditation questions are considered. ABET, as this is written, has not taken any official action on the questions that arise.

In this paper, the opinion will be expressed that outcomes assessment, as being implemented in the new criteria known as EC2000, will make it possible for institutions to show that their distance education programs are achieving the desired outcomes, provided of course that they are. The reasons for this opinion, which is solely that of the author, will be given.

Introduction

In engineering education, distance education programs have existed for many years. After World War II, engineering faculty rode trains to teach graduate classes to engineers in industry. Later, they drove, flew in university planes-whatever was necessary to meet the demand for postgraduate education. The use of television in a variety of forms commenced in the 1960s, and is now a fixture in graduate education in many colleges of engineering around the country, both in urban and rather remote areas. These programs supplement evening programs in some places, but frequently replace them, because they are academically and economically effective.

Industry has also wanted baccalaureate degree programs for their working technical professionals. A baccalaureate degree program presents many challenges that a postgraduate degree program does not have. It is longer, perhaps 120-128 semester hours compared with 30, has a more heterogeneous student body, and has a greater need for laboratories. In urban areas, evening programs have met the need. In some cases, programs on branch campuses have met the need. Often the faculty presenting the evening or branch program is virtually separate or distinct from the regular "day" program faculty. The Engineering Accreditation Commission of the Accreditation Board for Engineering and Technology (EAC/ABET) has been evaluating such programs for many years, and accrediting them. In some cases, at institutional option, the programs are evaluated separately and receive separate accreditation actions. In others, the program is offered as a single program, evaluated and accredited accordingly. 
In the 1990s, however, a number of factors combined to raise a new set of possibilities. The term distance education is commonly used to describe the process, which implies a geographical and/or temporal separation between students and faculty. These factors appear to be the ever-increasing need for professional development of the engineers and other technical professional employees in industry, the rise of new technologies such as the world wide web and video-conferencing, and the desire for increased interaction between colleges of engineering and industry.

As a result, a number of institutions are implementing distance education baccalaureate degree programs. ${ }^{2}$ Some use video conferencing, others the web, still others, videotape and satellite delivery. Some combine these techniques. Delivery of high quality education to these students presents many challenges, but also many opportunities. It meets an important need. All concerned, especially the students, want the programs to be accredited.

Engineering Criteria 2000

In the 1990s, EAC/ABET made major changes in accreditation criteria and processes. ${ }^{3}$ The phrase "EC2000" is associated with the new criteria, which depend heavily on an institution defining its objectives and outcomes, assessing the way in which it is meeting its objectives, and using the assessment results to improve the program. The criteria are now in effect, and will be fully operational for visits in the 2001-2002 accreditation cycle. There is a major role here for constituents, and industry is certainly a major constituent in the delivery of distance education engineering programs.

The provisions of EC2000 provide a clear framework for the accreditation of distance education programs. While the work cannot and should not be trivialized, the processes and techniques used for on campus students and programs should be extendable to programs with off campus students, those who take the courses by distance education techniques. The institution must define its objectives and outcomes, and include the distance education component in its results. The burden will be on the institution to demonstrate that its distance education students have a substantially equivalent attainment to those in conventional classes. There is a time-honored ABET maxim of "no surprises." There should not be any surprises regarding distance education delivery for the team when it arrives on site, and the institution should not be surprised to hear that the EAC/ABET is interested in its distance education efforts, if any. EAC will be interested in the results, not the process.

\section{Questions to Consider}

The new criteria have eight major headings or sections. Some questions that arise with regard to these programs are shown in the following section, connected with the appropriate criteria.

1. Students.

a. Is the objective to provide a program for traditional (18-22 year old) students? For nontraditional students? Both?

b. Distance education students, especially nontraditional students, may well have a combination of transfer credits and courses taken several years ago. How are these credits 
evaluated? How does the institution show that the students who come in with unusual backgrounds accomplish the objectives?

c. What credit, if any, is given for work experience, and how is it evaluated?

d. How are students advised and counseled?

e. Is the work of distance education students evaluated on the same basis as that of the on campus students? By the same people?

\section{Program Objectives}

a. Is the objective to provide a program that is indistinguishable on the public record from the on campus degree? Or does it lead to a separate degree program, which would require separate accreditation? If the latter, how are they distinguished, and is it clear to the public?

b. Are there objectives specifically only for the on or the off campus students? What are the differences? How and why are they implemented?

3. Program Outcomes and Assessment

a. How are the constituents for the off campus program involved in the determination of outcomes, and the assessment thereof.

b. Are similar outcomes assessment processes used for the on campus and off campus segments of the program? Why are differences implemented?

\section{Professional Component}

a. Is the program virtually identical with the on campus program? If so, presumably the professional component will be virtually unchanged.

b. Under what conditions are substitutions made for required courses? How are the decisions made?

c. Are the standards for coverage of material and for performance substantially identical for on and off campus students? How is the work evaluated? Who does it?

d. How is the major design experience implemented?

5. Faculty

a. Is the distance education program offered by the same faculty as the on campus program?

b. Does adjunct faculty offer the distance education program with some supplementation from the main campus?

c. What are the qualifications of the adjunct faculty?

6. Facilities. This may be the most important one.

a. What are the laboratories, computer facilities, and library facilities at the distance education sites?

b. Does the system in place allow and foster student-faculty interaction? How?

c. Does the system in place create a climate and an opportunity for professional development and professional activities? How shown? 
d. Does the system require students to learn to use modern engineering tools? How is this shown?

e. How is the WWW used?

\section{Support and Resources.}

a. Does the administration on the main campus support the program?

b. If there are partnership institutions at the distance education site (community colleges, four-year colleges, industrial coalitions), what sort of support do they provide? Show that it is effective. (There is a potential for a lot of politics here.)

c. What about distance education programs jointly offered by two or more main campuses?

\section{Conclusion}

Distance education is a technique for delivering high quality educational materials to appropriate students who are separated in time and space from the faculty. It is meeting an important national, even international need. It is a subject of much study and experimentation. In many informal settings, however, the opinion is often expressed that the phrase itself is short-lived, as the techniques of distance education will in many cases be found effective for traditional, on campus students. The boundaries are destined to become indistinguishable in the near future.

EC2000, the new accreditation criteria, place the burden of demonstration of quality and effectiveness of a program upon the institution that offers that program. Consequently, the criteria provide a good framework for the institutions to develop their program in, and enable the institutions to design an assessment process that shows how the criteria are met. There is a natural synergism between the two ideas. Distance education will perhaps test EC2000, challenging ABET/EAC to be sure that its evaluation methods are appropriate. At the same time, EC2000 provides educational institutions the opportunity to design and evaluate an effective distance education program that meets the needs of its constituents, and yet should meet the accreditation criteria in a way quite similar to that in which the conventional programs meet the criteria.

1 The Accreditation Board for Engineering and Technology, ABET, is studying distance education accreditation questions, but has not taken any formal position on the question. The thoughts expressed in this paper are strictly those of the author.

2 "Challenges of Delivering Undergraduate Engineering Programs to Place-Bound Members of the Technical Work Force." E. C. Jones, Jr., L. Van Brocklin, and R. Horton, Proceedings, Frontiers in Education, 1997, Pittsburgh, pp. 588-592.

3 Criteria for Accrediting Engineering Programs in the US." 2000-2001 Edition. Accreditation Board for Engineering and Technology. Baltimore, 2000. The latest edition of the criteria is available at http://www.abet.org.

EDWIN C. JONES, JR.

Edwin C. Jones, Jr., received the BSEE from West Virginia University in 1955, the Diploma of the Imperial College (DIC) from the Imperial College of Science and Technology in 1956, and a PhD from the University of Illinois in 
1962. He has served in the U S Army Signal Corps and has experience with General Electric and Westinghouse Electric. He was Assistant Professor of Electrical Engineering at the University of Illinois from 1962 until 1966. He joined Iowa State University in 1966, was appointed Associate Professor in 1967, Professor in 1972, and University Professor in 1995. He has been a Program Evaluator for IEEE, and has served on the Engineering Accreditation Commission and the ABET Board of Directors. He is a Fellow of ASEE, ABET, IEEE, and AAAS. 